\title{
Factors Affecting Foster Care Breakdown in Spain
}

\author{
Mónica López López ${ }^{1}$, Jorge F. del Valle ${ }^{1}$, Carme Montserrat ${ }^{2}$, \\ and Amaia Bravo ${ }^{1}$ \\ ${ }^{1}$ Universidad de Oviedo (Spain) \\ ${ }^{2}$ Universidad de Girona (Spain)
}

Breakdown of foster care has been defined as the situation in which one of the involved parties terminates the intervention before having achieved the goals established for the case plan. This work presents a study carried out with a Spanish sample of 318 closed cases of children who were placed in foster homes and kinship care. The data were collected through the exhaustive review of the child protection and foster placement files, complemented with interviews of the welfare workers in charge of each case. The rate of breakdown of the entire sample was $26.1 \%$, although it was significantly different in kinship care (19.7\%) and foster care $(31.2 \%)$. The results of this study indicate that the variables related to breakdown depend on the placement modality, either in foster care or kinship care. In the first case, the variables related to the child's characteristics are noteworthy, especially behavior and academic problems, with special relevance in the 9-12-year-old group, and in children who were previously in residential care. In contrast, in kinship care, the parents' problems (prison, mental health) and having some measure of guardianship are the most important. The fact of undergoing foster placement after having lived in various residential homes is transcendental. Lastly, the availability of economic resources and even the foster carers' studies seem to be related to foster breakdown.

Keywords: foster care, kinship care, child care, outcome assessment, disruption, breakdown, placement stability.

La ruptura del acogimiento familiar se ha definido como aquella situación en la que alguna de las partes implicadas causa una terminación de la intervención antes de haber alcanzado los objetivos establecidos en el plan de caso. Este trabajo presenta un estudio llevado a cabo en una muestra española de 318 casos cerrados de niños que fueron acogidos en familia ajena y extensa. Los datos se obtuvieron a través de la revisión exhaustiva de los expedientes de protección y acogimiento, complementada con entrevistas a los técnicos encargados de cada caso. La tasa de ruptura del conjunto de la muestra fue de $26,1 \%$, si bien fue significativamente diferente en familia extensa $(19,7 \%)$ que en familia ajena $(31,2 \%)$. Los resultados de este estudio indican que las variables relacionadas con la ruptura dependen de la modalidad del acogimiento, en familia ajena o extensa. En el primer caso destacamos las variables relacionadas con las características del niño, especialmente los problemas de conducta y escolares, con especial relevancia en el grupo de 9-12 años, y el haber estado en acogimiento residencial previamente. En cambio, en extensa resulta más importante la problemática en los padres (prisión, salud mental) y el tener una medida de tutela. También el hecho de que se realice el acogimiento tras pasar por hogares de acogida resulta trascendental. Finalmente, la disponibilidad de recursos económicos e incluso los estudios de los acogedores parecen ser variables relacionadas con la ruptura de la acogida.

Palabras clave: acogimiento familiar, familia extensa, familia ajena, protección infantil, evaluación de resultados, ruptura, permanencia.

This investigation was financed by the Ministerio de Trabajo y Asuntos Sociales del Gobierno de España by means of Project CN-06142 of the Universidad de Oviedo.

Correspondence concerning this article should be addressed to Jorge F. del Valle. Facultad de Psicología. Plaza Feijoo s/n. 33012 Oviedo. (Spain). Phone: +34-985103246. Fax:+34-985104141. E-mail.: jvalle@uniovi.es 
Foster care is a measure of child care for the cases in which it is necessary to separate children from their families for their own safety in situations of abuse. The children are placed with another family that voluntarily agrees to care for and educate them for a certain period of time, normally until they can return to their families or be placed with an adoptive family. Until the 1980s, the almost exclusive child care measure was admittance in a center for minors, but since then, new laws have defined the possibility of foster care, also establishing this option as the most desirable, especially for younger children.

In the past 20 years, foster care has been implemented in Spain very unequally, depending on the autonomous communities, but the most obvious conclusion is that it is still far from being the preferential measure, and residential care is still used frequently, even for very young children (Del Valle \& Bravo, 2003; Del Valle, Bravo, \& López, 2009). However, the scarce data also indicate that kinship care represents more than $80 \%$ of all the placements carried out (Del Valle \& Bravo, 2003) and that still very few unrelated families are willing to accept foster placements.

However, research on foster care is scarce and there are some essential aspects of its practice, such as outcome assessment, about which there are hardly any works. The study of breakdown of foster care, the theme of this article, should fall within the framework of program assessment because it is a negative, and obviously undesired, result. Breakdown can be defined as the situation in which one of the parties involved prematurely terminates the intervention before having achieved the goals established in the case plan (Berridge \& Cleaver, 1987). As will be seen below, foster parents, the children themselves, or the authorities frequently decide to put a hasty end to a placement instead of carrying on with the foreseen plans, with all the negative consequences this may have for the different parties involved, especially for the children. Breakdown is a type of result that should be assessed in detail in order to prevent it, decreasing the known risk factors.

Given the importance of data from the national setting, not only because of the lack of studies, but because of the role that cultural peculiarities may play, this article will present an empirical study of the factors associated with breakdown of foster care in a Spanish sample.

\section{Rates of Breakdown and its Consequences}

The rate of breakdowns can be considered an indicator of the quality of the foster care programs (Aldgate \& Hawley, 1986; Smith, 1994). This rate varies a great deal at the international level, because it is estimated that between 20 to $50 \%$ of placements ends this way (Berry \& Barth 1990; Fratter, Rowe, Sapsford, \& Thoburn, 1991; Millham, Bullock, Hosie, \& Haak, 1986; Minty, 1999; Sallnäs, Vinnerljung, \& Westermark, 2004; Stone \& Stone, 1983).
Various authors indicate that foster breakdown may lead to very negative consequences, not only for foster children, but also for foster families and foster placement programs (Aldgate \& Hawley, 1986; Berridge \& Cleaver, 1987; Chipungu \& Everett, 1994; Fanshel, Finch, \& Grundy, 1990; Rich, 1996; Wade, Biehal, Clayden, \& Stein, 1998). In most cases, breakdown involves a change in the child's life, either changing the neighborhood, the school, or the reference people. Such instability can threaten the fosterchild's well-being, increasing the probability of suffering from emotional and behavior problems (Newton, Litrownik, \& Landsverk, 2000), as well as of attachment difficulties (Schwartz, Ortega, Guo, \& Fishman, 1994). International research has shown than children who display oppositional defiant disorder or other externalizing behavior disorders (fights, delinquency, etc.) have undergone the most placement changes (James, Landsverk, \& Slymen, 2004; Palmer, 1996). Children who undergo a larger number of changes will also be more likely to obtain worse academic results and to suffer from other problems at school (Biehal, Clayden, Stein, \& Wade, 1995; Eckenrode, Rowe, Laird, \& Brathwaite, 1995; Sallnäs et al., 2004). Foster breakdown has also been linked to increased difficulties for these children after their transition to an independent life, including antisocial behavior, chronic unemployment, delinquency, psychoactive substance consumption, or difficulties in their personal relations, among other problems (Fanshel et al., 1990; Festinger, 1983; Mech, Ludy-Dobson, \& Hulseman, 1994). It is difficult for the studies to establish causal relations, but they seem to indicate that behavior problems foment breakdowns and, in turn, changes worsen or aggravate such problems.

Such unfortunate endings also have negative effects on the foster care program itself (Patten, 2005; Smith, 1994) because they can lead to demoralization of the foster parents and even make them want to stop collaborating with the placement program (Brown \& Calder, 1999; Fisher, Gibbs, Sinclair, \& Wilson, 2000; Gilbertson \& Barber, 2003; Vanderfaeillie, Van Holen, \& Coussens, 2008). Nor should the discouraging effects that such failures can have on child welfare workers be neglected (Aldgate \& Hawley, 1986; Berridge \& Cleaver, 1987; Cautley, 1980; Wade et al., 1998). This aspect should be analyzed in detail in the case of Spain because it might, at least partially, explain the lack of a greater implementation of foster care (Del Valle et al., 2009).

\section{Breakdown Risk Factors}

International research has revealed a series of factors associated with foster breakdown. These factors, which we shall call risk factors, can be grouped in four spheres: the characteristics of the foster children, of the family of origin, of the foster family, and, lastly, of the placement process. In the following paragraphs, we shall summarize the main findings of international research on these four aspects. 


\section{Characteristics of the foster children}

There is no doubt that age is a very important factor, and diverse studies have shown that, the older children are at placement, the higher the probability of foster breakdown (Harwin, Owen, Locke, \& Forrester, 2001; James et al., 2004; Parker, 1966; Terling-Watt, 2001; Trasler, 1960; Webster, Barth, \& Needell, 2000). Specifically, the results indicate that adolescent placements have the highest risk of disruption (Berridge, 1997; Napier, 1972; Pardeck, 1984; Rowe, Cain, Hundleby, \& Garnett, 1989). It is logical to think that an adolescent's educational difficulties plus the onset of the typical changes of this stage might make it more likely for the families to decide to put an end to placement at these ages.

Likewise, there is evidence that behavior problems, particularly aggressiveness, cause higher levels of breakdown (Barber, Delfabbro, \& Cooper, 2001; Barth \& Berry, 1988; Berridge, 1997; Cooper, Peterson, \& Meier, 1987; Farmer, Lipscome, \& Moyers, 2005; James et al., 2004; Newton et al., 2000; Palmer, 1996; Pardeck, 1984; Proch \& Taber, 1985; Sallnäs et al., 2004; Stone \& Stone, 1983; Widom, 1991). Behavior problems seem to be the most robust predictor of all those analyzed in foster children.

The presence of health problems (Leslie et al., 2005; Parker, 1966) also seems to increase the risk of foster breakdown.

There is less agreement with regard to the sex of the foster child, because some studies state that boys are at more risk of breakdown than girls (Palmer, 1996; Webster et al., 2000), whereas other investigations find no such relation (James et al., 2004; Vanderfaeillie et al., 2008).

Evidently, research has also indicated that some factors are related to a lower probability of breakdown. It seems less likely when the children are younger (Parker, 1966) and more socially adapted (Stone \& Stone, 1983), when their history of maltreatment is not so severe (Cooper et al., 1987), and when they are highly motivated towards placement (Sinclair \& Wilson, 2003).

\section{Context of the family of origin}

The characteristics of the family of origin have also been associated with the probability of suffering foster breakdown. Some studies have shown that children whose parents are addicted to alcohol or other drugs undergo more foster breakdowns than children whose family of origin has no such history of drug addiction (Cooper et al., 1987; Pardeck, 1984).

With regard to the severity of prior child care history, diverse authors agree that children who are in child care because of sexual or physical abuse have a higher probability of breakdown than those who are in child care because of negligence (Barber et al., 2001; Oosterman, Schuengel, Slot,
Bullens, \& Doreleijers, 2007; Webster et al., 2000). Barber et al. (2001) suggest that this result may be modulated by other factors such as age and behavior, whereas Kalland and Sinkkonen (2001) found no differences among children as a function of the kind of maltreatment suffered. However, Stone and Stone (1983) found that children who suffer chronic problems in their family setting have a lower probability of successful placement than those who experience acute problems.

Lastly, it has been shown that frequent contact with the parents can act as a protector factor against breakdown (Berridge \& Cleaver, 1987; Fratter et al., 1991; Millham et al., 1986) although this is controversial.

\section{Characteristics of the foster family}

The characteristics of the foster family affect foster breakdown in various ways. One that has received much attention is the presence of biological children in the foster family, which emerges as a factor associated with breakdown in diverse studies (George, 1970; Kalland \& Sinkkonen, 2001; Parker, 1966) because it can lead to situations of jealousy and rivalry. According to Trasler (1960), this variable is modulated by age and sex: foster children in families with biological children of the same sex and with an age difference of not more than 3 years are more likely to undergo breakdowns.

Diverse investigations clearly indicate that the training and support provided to foster parents reduce the probability of breakdown (Berridge \& Cleaver, 1987; Cautley, 1980; Farmer et al., 2005; Kalland \& Sinkkonen, 2001; McDonald, Lieberman, Partridge, \& Hornby, 1991).

Kalland and Sinkkonen (2001) have also reported other protection factors that attenuate the risk of breakdown, such as the foster family receiving the support of social workers, local authorities, friends, and relatives, receiving the necessary information about the foster child, and cooperation between foster and biological parents.

Lastly, when the foster parents are related to the child (kinship care), there is less probability of breakdown (Chamberlain et al., 2006; Courtney \& Barth, 1996; Del Valle, López, Montserrat, \& Bravo, 2009; Gleeson \& Hairston, 1999; James et al., 2004; Minty, 1999; Sallnäs et al., 2004; Webster et al., 2000).

\section{Characteristics of the placement process}

The number of contacts and a good relationship between the foster child and the social workers have been indicated by diverse investigators as factors that decrease the risk of breakdown (Kallan \& Sinkkonen, 2001; Stone \& Stone, 1983; Walsh \& Walsh, 1990). In contrast, having experienced the interruption of a previous measure seems to increase the risk of subsequent breakdowns (McDonald 
et al., 1991; Webster et al., 2000), specifically, having undergone previous changes in residential care has been related to instability in later placements (Sallnäs et al., 2004; Webster et al., 2000).

Trasler (1960) showed that placements were more successful if the child was placed with a sibling or if the foster family had another foster child. This is confirmed in other studies (Berridge, 1997; Drapeau, Simard, Beaudry, \& Chardonneau, 2000; Thorpe \& Swart, 1992), although Parker (1966) found no differences in this sense, and George (1970) found that foster children placed with their siblings were less successful in foster care. Leathers (2006) added the nuance that children who were placed alone but who, at some time, had been placed with their siblings have a higher risk of breakdown than those who were placed with their siblings the whole time.

Below, we present an empirical study carried out with a sample of foster and kinship-family placements in Spain, among which there is a group that ended in breakdown. In view of the inexistence of prior studies in our country on this topic, the purpose of the article is to determine the variables associated with these disruptions through the analysis of diverse factors indicated in the international investigations that are reviewed above.

\section{Method}

\section{Participants}

This empirical study is the continuation of a more extensive investigation in which foster care in Spain was analyzed (Del Valle, López, Montserrat, \& Bravo, 2008) in a sample of 694 cases in six autonomous communities that are considered to be representative of the entire conjoint State (more than $70 \%$ of all the placements in Spain were carried out in these six communities). This sample included some open and some closed cases (approximately the same number) for each autonomous community. In this article, we only deal with the closed files (to be able to confirm the reason for closing, either breakdown or some other reason), which leads to a sample of 318 placements, of which 176 are in a foster family and 142 are in kinship care. These 318 cases belong to five autonomous communities, because one of the communities of the general study had very few closed cases. The sample in this article are from the communities of Castilla y Leon $(n=36)$, Galicia $(n=44)$, the Valencian Community $(n=61)$, Catalonia $(n=84)$, and Madrid $(n=93)$. The sizes of the samples in each community were collected in proportion to the number of placements carried out in each one, according to the study of Del Valle and Bravo (2003).

In this sample of 318 cases whose intervention had ended, 83 cases $(26.1 \%)$ had been closed because of breakdown. The rest of the cases were closed because of a technical decision to change or conclude the measure (adoption, family reunification, a more adequate placement, etc.) $-35 \%$-or because the child came of age (32.7\%), and the remaining cases were due to other causes.

\section{Variables, Instruments, and Procedure}

Data were collected by reading the child care files. For this purpose, we previously elaborated an instrument that established a broad array of variables referring to the aspects used for the theoretical review: the children, the biological and foster families, and the child care process. Each variable was coded with its possible values, mostly dichotomic, in terms of presence or absence (for example, mental health problems in parents). The complete instruments can be consulted in the general study (Del Valle et al., 2008). In them, we contemplated the main variables that were relevant for breakdown in the theoretical review and, logically, we also included many more variables. The ones analyzed in this article are presented in Tables 1 and 2 of the results and are not listed here to avoid repetition and to save space. The tables present the variables that have already been analyzed in the theoretical part of the international scientific literature, but we have added other variables of interest in the case of our Spanish sample.

In addition to reading the files, we carried out a final interview with the social workers who were in charge of the cases to contrast possible doubts or to complete information. This interview was used to record these professionals' ratings of some more subjective aspects such as the degree of cooperation of the biological families. This variable is included in this article and was collected by asking these professionals whether the biological family could be classified as cooperative, oppositionist, ambiguous, or absent (for the father and mother separately) with regard to the placement process.

To collect the data, specially trained investigators went to each of the autonomous communities, once they had obtained permission from the competent authorities.

\section{Data Analysis}

For this study, all the categorical variables were dichotomized as presence or absence of each factor to be analyzed with regard to the breakdowns. We performed $\chi^{2}$ test between each factor and the variable breakdown-no breakdown, so we applied the continuity correction for $2 \times 2$ tables. In the case of quantitative variables, we used analysis of difference of means. All the analyses were carried out separately for foster family and kinship care, because it is a well known fact that these are very different situations with regard to the characteristics we are assessing, such as the type of child, biological family, foster family, and process (Del Valle et al., 2008; Del Valle, López, Montserrat, \& Bravo, 2009; Farmer \& Moyers, 2008; Jiménez \& Palacios, 2008; Montserrat, 2007). 


\section{Results}

The rate of breakdown in the conjoint sample was $26.1 \%$, although it was significantly different in kinship care $(19.7 \%)$ and in foster care $(31.2 \%), \chi^{2}(1,318)=4.84$, $p=.028$. This percentage is also very variable among the autonomous communities, with the following distribution for each one: $12.1 \%, 19.4 \%, 22.7 \%, 27.4$, and $45.9 \%$ (as the goal of the investigation was not to establish comparisons of effectiveness among the territories but to obtain a large representative sample of the Spanish territory, we will not comment the data with reference to each specific community).
A noteworthy criterion in the investigations is age, because breakdowns are more frequent among older children. In our results, this was quite complex, because we used two different ages: age at placement and age at closure or cessation of placement. For age at placement closure, the differences of mean age between the breakdown and nobreakdown groups were nonsignificant, either for foster care (breakdown: $M=12.1, S D=5.02$; no breakdown: $M=11.46, S D=6.53), t(176)=.67, p=.503$, or for kinship care (breakdown: $M=11.86, S D=4.66$; no breakdown: $\mathrm{M}=13.84, S D=5.33, t(142)=-1.80, p=.074$. That is, the ages of the children who concluded their placement in breakdown were high, on average, these children

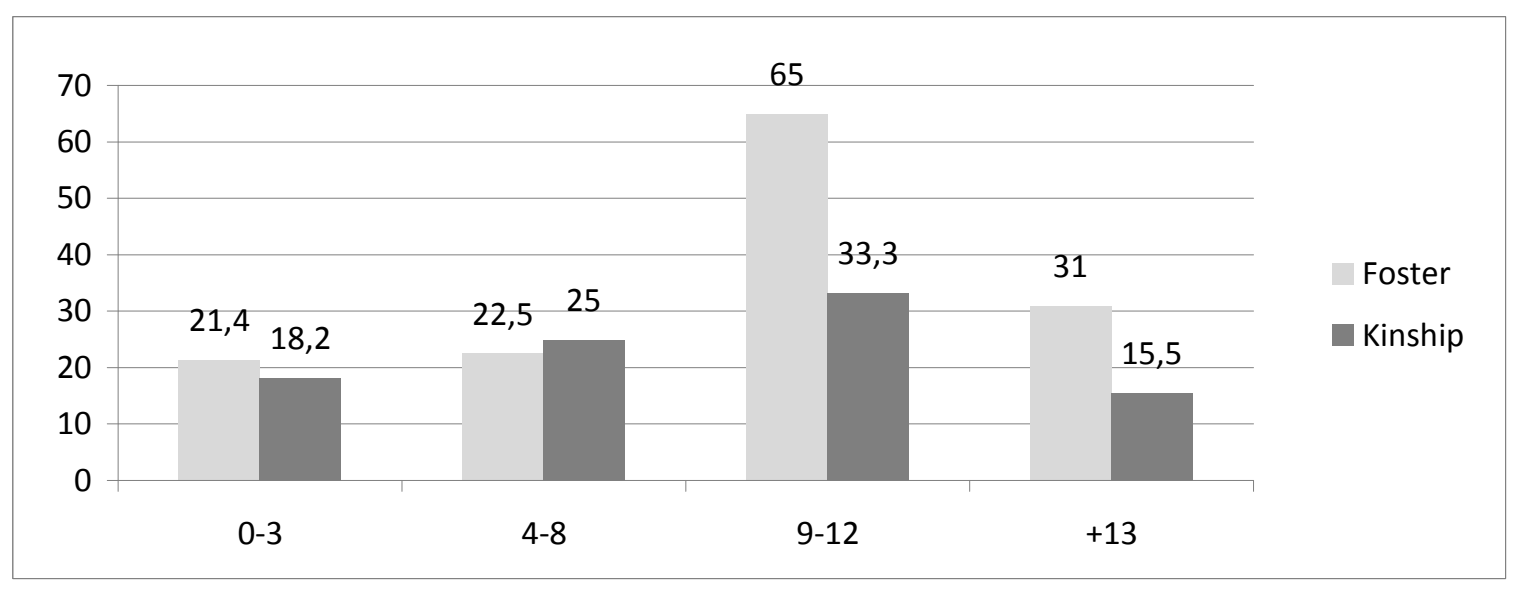

Figure 1. Rate of breakdown by age group at time of closure.

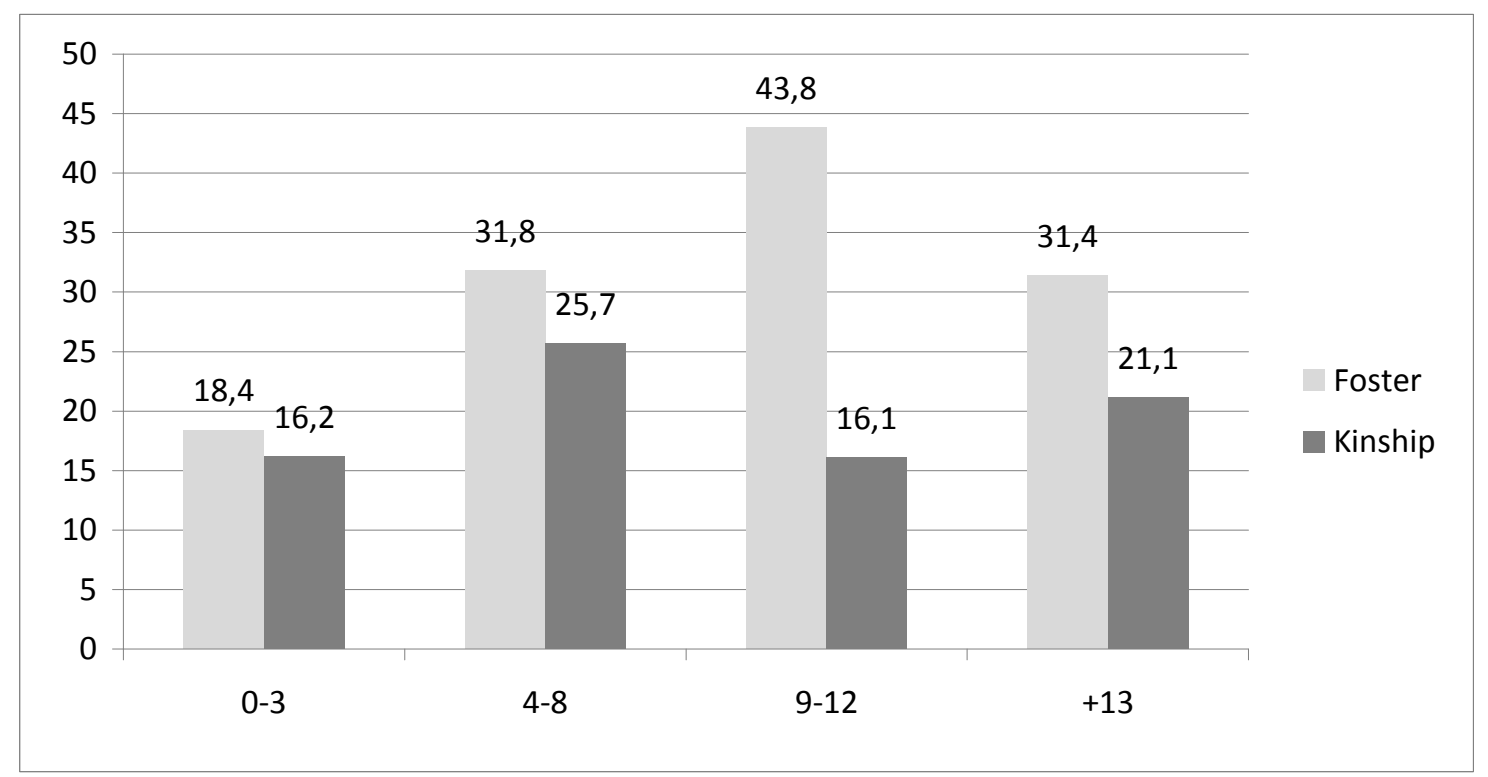

Figure 2. Rate of breakdown by age group at placement. 
were adolescents. It is important to mention that no age differences were found regarding cases that were closed for reasons other than breakdown.

When considering the children's age at placement, no significant differences were found in kinship care (breakdown: $M=8.59, S D=8.62$; no breakdown: $M=8.62, S D=5.54), t(142)=-.02, p=.980$. However, we did observe that breakdowns in foster care referred mainly to children placed at older ages (breakdown: $M=9.37, S D=4.52$; no breakdown: $M=7.69, S D=5.30$ ), $t(176)=2.16, p=.033$.

With regard to placement duration, as expected, there were significant differences, because the breakdowns caused shorter durations. In effect, duration in years was significantly shorter when breakdown occurred, both for foster family (breakdown: $M=2.62, S D=3.04$; no breakdown: $M 3.68, S D=2.26), t(173)=2.52, p=.006$, and for kinship care (breakdown: $M=3.26, S D=3.45$; no breakdown: $M=5.21, S D=4.27), t(138)=2.23, p=.028$. Nevertheless, we observed that duration was always longer in kinship care. However, when examining the distribution of the duration of the cases with breakdown, we observed high variability but, both in kinship care and in foster care, one third of the breakdowns occurred before one year in placement had gone by and half of them before two years had gone by.

For the sake of clarity, we present the relation of age with breakdown in terms of rate of breakdown by age group. In Figure 1 are indicated the rates of breakdown as a function of the child's age at closure, both in foster and in kinship care. It shows that the group with the highest risk of breakdown is the 9-12-year age group, because $65 \%$ of the cases that are closed at this age in foster family are due to breakdown (the highest rates in kinship care also occur in this age group, but the figure is much lower than in foster care). In Figure 2 are presented the rates of breakdown for the children's age group at placement. In foster care, the highest risk was in the 9-12-year age group, with a rate of $43.8 \%$, and here, the kinship care situation was quite different, with the 4-8-year age group displaying the highest rate $(25.7 \%)$.

Tables 1 and 2 show the results of the analyses that relate breakdown or no breakdown with diverse variables belonging to the four groups: children's characteristics, biological parent's characteristics, foster family's characteristics, and characteristics of the process. Table 1 shows that, for foster family, breakdowns are intensely related to the children's characteristics, because of behavior problems, academic performance, receiving psychological treatment, and even intellectual disability (with effect sizes of phi between .25 and .45 , which are considered moderate). Although behavior and academic problems had a very high correlation $(\varphi=.71, p=.001)$, the correlation between such problems and receiving psychological treatment, albeit significant, was moderate $(.20$ and .16 , respectively). Lastly, intellectual disability affected 10 cases, of which 9 ended in breakdown, and all 9 presented behavior and academic problems. In contrast, none of the forms of maltreatment received or justifications for child care were related to placement ending in breakdown.

With regard to the intervention process, the only factor related to breakdown was having been previously in residential care $(81.1 \%$ of the cases of breakdown had been in residential care before, versus $62.8 \%$ of cases concluded with no breakdown). In contrast, none of the variables related to the family of origin had an impact on foster breakdown, although the ambiguous attitude of the mother regarding placement (sometimes oppositionist, sometimes cooperating) almost reached statistical significance.

The study of the characteristics of the foster family showed that earning more income (more than 24,000 €/ year) and having higher university studies was related to a lower number of breakdowns. But highly debated variables in scientific research, such as having biological children or having children younger than the foster child, were not related in our work.

The results in kinship care are quite different, so we decided it was pertinent to study both groups separately. Firstly, in contrast to the foster family, the children's characteristics had no relation to breakdown, except for the children who had received emotional abuse (higher risk of breakdown). Behavior and academic problems appeared in about one half of the cases, but were not a risk factor for breakdown. With regard to the process, having been in residential care was again linked to breakdown, but the difference was much clearer in this case because $46.4 \%$ of the breakdown group had lived in residences, but only $14 \%$ of the no-breakdown group had undergone this experience. Moreover, in the case of kinship care, children who were subject to a care order (not a voluntary arrangement) had a higher probability of breakdown.

In addition, in the case of kinship care, a measure of guardianship (not ward) was related to a higher probability of breakdown.

In kinship care, in contrast to foster care, two characteristics of the biological parents were associated with risk of breakdown. These were fathers who were in prison and mothers with mental health problems.

Lastly, regarding the characteristics of the carers, we observed that when income was lower than $6.000 €$ per year, there was a higher risk of breakdown. In kinship care, we did not study the presence of biological children because most of the carers were the grandparents and, even if their own children were living at home, they were probably either adults or else the biological parents of the children, so this is not related to the meaning of this variable in kinship care. 
Table 1

Placement in Foster Family. Difference of Impact of Factors on Breakdown

\begin{tabular}{|c|c|c|c|c|c|c|}
\hline & & $\begin{array}{c}\text { Breakdown } \\
(N=55) \\
\%\end{array}$ & $\begin{array}{c}\text { No breakdown } \\
(N=121) \\
\%\end{array}$ & $x^{2}$ & $p$ & $\begin{array}{c}\text { Effect } \\
\text { size } \\
(\varphi)\end{array}$ \\
\hline \multirow{10}{*}{ 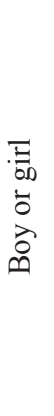 } & Sex (male) & 43.6 & 49.46 & 0.33 & .568 & \\
\hline & Presence of health problems & 17.3 & 24 & 0.57 & .451 & \\
\hline & Intellectual disability & 14.5 & 0.8 & 11.98 & .001 & .29 \\
\hline & Presence of behavior problems & 81.6 & 34 & 27.65 & .000 & .45 \\
\hline & Has received psychological treatment & 32.7 & 13.2 & 8.82 & .005 & .22 \\
\hline & Academic performance problems & 69.6 & 43 & 7.67 & .006 & .25 \\
\hline & Physical abuse & 18.2 & 12.4 & 0.62 & .432 & \\
\hline & Physical negligence & 34.5 & 42.1 & 0.62 & .430 & \\
\hline & Emotional abuse & 21.8 & 17.4 & 0.24 & .621 & \\
\hline & Total abandonment or renouncement & 20.0 & 24.0 & 0.15 & .698 & \\
\hline \multirow{5}{*}{$\begin{array}{l}n \\
0 \\
0 \\
0 \\
0\end{array}$} & Prior measure of residential care & 81.8 & 62.8 & 5.51 & .019 & .19 \\
\hline & Prior breakdown of foster care & 23.6 & 14.0 & 1.83 & .177 & \\
\hline & Measure of guardianship & 90.9 & 81.8 & 1.76 & .185 & \\
\hline & Visits & 49.1 & 61.2 & 1.79 & .182 & \\
\hline & Frequent visits & 30.4 & 31.0 & 0.00 & .999 & \\
\hline \multirow{12}{*}{ 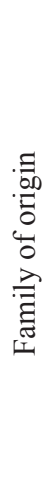 } & Father's drug addiction & 16.4 & 19.0 & 0.04 & .833 & \\
\hline & Father's alcoholism & 5.5 & 14.0 & 1.99 & .159 & \\
\hline & Father's mental health problems & 5.5 & 1.7 & 0.84 & .359 & \\
\hline & Father in prison & 10.9 & 12.4 & 0.01 & .975 & \\
\hline & Mother's drug addiction & 16.4 & 22.3 & 0.49 & .480 & \\
\hline & Mother's alcoholism & 5.5 & 10.7 & 0.52 & .396 & \\
\hline & Mother's mental health problems & 21.8 & 17.4 & 0.24 & .621 & \\
\hline & Mother in prison & 12.7 & 15.7 & 0.08 & .775 & \\
\hline & Mother does not intervene or is absent & 14.5 & 22.3 & 0.99 & .321 & \\
\hline & Mother cooperates & 26.3 & 34.7 & 1.68 & .196 & \\
\hline & Mother's opposition & 9.1 & 10.7 & 0.00 & .947 & \\
\hline & Mother ambiguous & 23.6 & 11.6 & 3.37 & .067 & \\
\hline \multirow{6}{*}{ 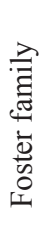 } & Foster family is a couple & 81.8 & 78.3 & 0.11 & .743 & \\
\hline & Multiple placement & 14.5 & 22.5 & 1.04 & .309 & \\
\hline & Presence of children in foster family & 61.8 & 55.0 & 0.47 & .495 & \\
\hline & Foster parents' children younger than foster child & 20.0 & 15.9 & 0.04 & .842 & \\
\hline & Income of more than 24,000 euros & 16.4 & 33.1 & 4.45 & .035 & .17 \\
\hline & Higher studies & 21.8 & 45.5 & 7.99 & .005 & .23 \\
\hline
\end{tabular}

\section{Discussion}

Firstly, we consider it essential to underline the rate of breakdown we found: almost one third of the cases in foster care and one fifth in kinship care. These figures fall within the known facts in international research (between 20-50\%) for the case of foster care (Berry \& Barth 1990; Fratter et al., 1991; Millham et al., 1986; Minty, 1999; Sallnäs et al., 2004; Stone \& Stone, 1983), although in the case of kinship care, the proportion is slightly lower. This reinforces the idea of the latter's higher stability (Farmer, 2009).

The children's characteristics, specifically, behavior and academic problems, were unanimously acknowledged in the investigation as one of the main reasons for breakdown (Barber et al., 2001; Barth \& Berry 1988; Berridge, 1997; Cooper et al., 1987; Farmer et al., 2005; James et al., 2004; Newton et al., 2000; Palmer, 1996; Pardeck, 1984; Proch \& Taber 1985; Sallnäs et al., 2004; Stone \& Stone, 1983; Widom, 1991). In our results, this is confirmed, but only in the case of foster care, because in kinship care, this is not a reason for breakdown. Regarding this, readers are reminded that foster placements usually present profiles of children with greater behavior and developmental problems than children in kinship placements (Del Valle et al., 2008), which could partially explain this situation. But, on the other hand, it is quite possible that relatives accept that they 
Table 2

Placement in Kinship Care. Difference of Impact of Factors on Breakdown

\begin{tabular}{|c|c|c|c|c|c|c|}
\hline & & $\begin{array}{c}\text { Breakdown } \\
(N=28) \\
\%\end{array}$ & $\begin{array}{c}\text { No breakdown } \\
(N=114) \\
\%\end{array}$ & $\chi^{2}$ & $p$ & $\begin{array}{c}\text { Effect } \\
\text { size } \\
(\varphi)\end{array}$ \\
\hline \multirow{6}{*}{ 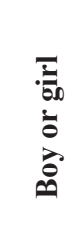 } & Sex (male) & 42.9 & 49.1 & .15 & .701 & \\
\hline & Presence of health problems & 16.7 & 33.0 & 1.70 & .192 & \\
\hline & Intellectual disability & 0 & 3.5 & .13 & .713 & \\
\hline & Presence of behavior problems & 65.0 & 48.2 & 1.21 & .271 & \\
\hline & Has received psychological treatment & 28.6 & 12.3 & 3.40 & .065 & \\
\hline & Academic performance problems & 68.4 & 50.6 & 1.30 & .204 & \\
\hline \multirow{9}{*}{ 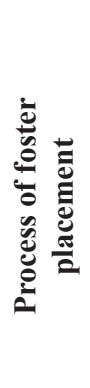 } & Physical abuse & 14.3 & 9.6 & .14 & .710 & \multirow{4}{*}{.27} \\
\hline & Physical negligence & 46.4 & 36.0 & .65 & .421 & \\
\hline & Emotional abuse & 53.6 & 22.8 & 8.92 & .003 & \\
\hline & Total abandonment or renouncement & 17.9 & 21.1 & .01 & .909 & \\
\hline & Prior measure of residential care & 46.4 & 14.0 & 12.59 & .000 & \multirow{2}{*}{.32} \\
\hline & Prior breakdown of foster care & 25.0 & 9.6 & 3.50 & .061 & \\
\hline & Measure of guardianship & 78.6 & 56.1 & 3.84 & .050 & \multirow{8}{*}{.22} \\
\hline & Visits & 42.9 & 57.0 & 1.29 & .256 & \\
\hline & Frequent visits & 58.3 & 37.3 & 1.06 & .303 & \\
\hline \multirow{11}{*}{ 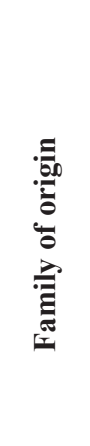 } & Father's drug addiction & 32.1 & 40.4 & .34 & .560 & \\
\hline & Father's alcoholism & 25.0 & 14.0 & 1.27 & .261 & \\
\hline & Father's mental health problems & 3.6 & .9 & .04 & .850 & \\
\hline & Father in prison & 42.9 & 19.3 & 5.63 & .018 & \\
\hline & Mother's drug addiction & 28.7 & 46.5 & 2.26 & .133 & \\
\hline & Mother's alcoholism & 3.6 & 15.8 & 1.94 & .164 & \multirow{3}{*}{.26} \\
\hline & Mother's mental health problems & 32.1 & 9.6 & 7.63 & .006 & \\
\hline & Mother in prison & 28.6 & 14.9 & 2.03 & .155 & \\
\hline & Mother does not intervene or is absent & 17.9 & 30.7 & 1.25 & .263 & \\
\hline & Mother cooperates & 46.4 & 39.5 & .21 & 648 & \\
\hline & Mother's opposition & 3.6 & 2.6 & .00 & .999 & \\
\hline \multirow{7}{*}{ 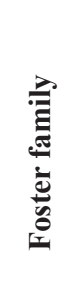 } & Mother ambiguous & 21.4 & 9.6 & 1.95 & .163 & \\
\hline & Foster family is a couple & 71.4 & 64.0 & .27 & .606 & \\
\hline & Multiple placement & 35.1 & 39.3 & .04 & .845 & \\
\hline & Presence of children in foster family & - & - & - & - & \\
\hline & Foster parents' children younger than foster child & - & - & - & - & \multirow{3}{*}{.20} \\
\hline & Income of less than 6,000 euros & 35.7 & 15.8 & 4.50 & .035 & \\
\hline & No elemental studies & 32.1 & 21.9 & .79 & .375 & \\
\hline
\end{tabular}

must continue to care for the children despite the problems they present, whereas foster parents have less personal commitment with the case and find it easier to decide that, in view of the difficulties, they do not wish to continue.

The results also indicate that the cases of breakdown have been in psychological treatment more frequently, a fact that could be interpreted positively because it means that these problems are being treated or at least, they have been treated at some time during the child care intervention. In any event, there is no doubt that foster children's behavior and academic problems affect their relations with their foster parents and can become an important source of stress for the latter (Stern \& Smith, 1999), leading to the deterioration of the link between children and carers (Gries et al., 2000; Heller, Smyke, \& Boris, 2002; Laan, Loots, Janssen, \& Stolk, 2001; Milan \& Pinderhughes, 2000; Thompson, Authier, \& Ruma, 1994).

Age has also been considered a key factor, in the sense of increased risk of breakdown at higher ages. Our results allow us to qualify this issue. On the one hand, age at placement should be differentiated from age at closure or breakdown, a point that has habitually not been taken into account in the research. In any event, the 9-12-year age group represents the highest risk of breakdown, no matter whether this age refers to the moment of closure $(65 \%$ of the cases closed at this age were due to breakdown), or to 
age at placement $(43.8 \%$ of the placements at these ages ends in breakdown). It is important to underline that this refers to foster family, because in kinship care, age is not so relevant (probably related to the fact that neither are behavior problems so relevant). International research indicates that older children and adolescents have more breakdowns, and this is also confirmed when reviewing the absolute figures of our study, because all the cases that ended in breakdown- $49 \%$ in foster care and $46.4 \%$ in kinship care-were 13 years old or older. But in relative terms, it should be taken into account that, of all the cases that were closed at these ages, only $31 \%$ in foster care and $15 \%$ in kinship care were breakdowns. With regard to age at placement, the placements carried out in adolescence have a $20 \%$ breakdown rate in foster care, a lower percentage than that found for ages 9-12 years and even for 4-8 years. Thus, in terms of at-risk ages, placements carried out between 9-12 years are more likely to end in breakdown.

In our results, an important factor related to breakdowns, both in fosters and in kinship care, is having been previously in residential care. Previous experience in residential care may mean that the minors must undergo a new change and adaptation when being placed in a foster home, which is aggravated when such residential care means that placement occurs later on, at ages of higher risk, over 9 years of age. In effect, in our results, we found that the 9-12-year age group in foster care presented more cases of prior residential care (almost 90\%, versus a general average of $68 \%$ ). Thus, future investigations should examine whether the fact that the 9-12-year age group displays a higher risk of breakdown is because the children have been in residential care more frequently, or whether this factor is related to breakdowns because it leads to placements at preadolescent ages, which are more challenging for the adaptive process.

However, our data do not coincide with the international studies that found that changes and interruptions in prior placements are usually related to higher risk of subsequent breakdown (McDonald et al., 1991; Webster et al., 2000). In our sample, having undergone previous breakdown of foster care had no statistically significant relation with current breakdown. This probably occurs to a greater extent when there were several previous breakdowns, which is very common in Anglo Saxon countries. In contrast, in our sample, the great majority of the children had only had one experience of breakdown, and this does not seem to be sufficient to have a subsequent impact.

The results do not reveal any relations between breakdown and children's experiences of abuse, in accordance with Kalland and Sinkkonen (2001), with the exception of those who suffered emotional abuse in kinship care.

In kinship care, being placed under a care order instead of a voluntary arrangement is related to breakdown, probably because this situation sometimes involves the parents' opposition and therefore, conflict among the families, a fact that has been noted by other authors (Farmer, 2009). The appearance of variables such as the incarcerated father or the mother with mental health problems, which is related to breakdown in kinship care, could be interpreted similarly. In both cases, the discord with the kinship carers could generate a conflict that leads to foster breakdown. However, it is noteworthy that no factor related to the biological family, including visits with the child, is associated with breakdown in foster care. It seems that the placement process protects the carers from the vicissitudes of all these problems, which is very positive. In contrast, the ties between the child's parents and the kinship carers are much closer, mainly because they are usually the grandparents, and they are therefore more exposed to problems and conflict.

A fact that appears in our study, and which has no antecedents in research, is the relation between high educational and economic level and the lower probability of breakdown in foster family, indicating that the availability of personal and material resources may make placement more resistant. In the case of kinship care, economic and educational precariousness are well known (Del Valle, Álvarez-Baz, \& Bravo, 2002; Farmer, 2009; Jiménez \& Palacios, 2008; Montserrat \& Casas, 2006). In the present study, we confirmed that the lowest level of income was related to a higher number of breakdowns (but not with a lower educational level), which seems to confirm our suggestion about available resources.

\section{Conclusions}

The results reveal a moderate breakdown rate, compared to what we know from international research, and it is even low for the case of kinship care. It is clear that the risk factors of breakdown may be different depending on the type of placement, foster or kinship. In the first case, we underline the variables related to the child's characteristics, especially behavior and academic problems, with particular relevance in the 9-12-year age group, which is the placement age with the highest probability of breakdown and is also associated with having previously been in residential care. In contrast, the children's problems are tolerated to a greater extent in kinship care and are not a cause of breakdown, and in this case, the most important problem is the parents (prison, mental health) and having the measure through guardianship. Placement after having been in several residential homes instead of placement from the beginning in a foster homeas is common - also has a significant impact. Lastly, the availability of economic resources and even the educational level of the carers seem to be very important.

In view of these results, we think that placement programs should attempt to avoid breakdowns by means of adequate support to the families. On the one hand, they should work on coping with behavior problems that are displayed with more 
force in preadolescence and adolescence, both at the level of initial training and by means of psychological support services during placement. Carers need to receive training about education, development, and child behavior, they need to establish relations with services and professionals, etc., before the placement and also during the placement, especially when the children have special profiles. In kinship care, it is important to remember the presence and influence of the family relationship with the children's parents and the enormous problems they present. Working on family mediation or child care and reinforcement of the carers is essential. However, intensive intervention along the lines of therapeutic placement should be encouraged for children with more complex profiles. This has a long tradition in the USA, and the appraisals show a high level of efficacy (Chamberlain, 1990; Chamberlain, Leve, \& DeGarmo, 2007; Hudson, Nutter, \& Galaway, 1994), and it is now being implemented in various European countries. Likewise, systems to detect fragile situations must be created, and this requires exhaustive follow-ups, because many families do not report placement problems until they are overwhelmed by them and, by then, intervention is insufficient.

Residential care for children should be avoided if at all possible. We should have enough placement programs in their diverse typologies to make emergency or special placements possible, so children can go directly to a foster home, especially those under 8 years of age. Residential care plays an important role in child care, but being the place where small children wait for placement with a foster family should not be one of their roles (Bravo \& Del Valle, 2009; Del Valle, Bravo, \& López, 2009).

Lastly, the study has various limitations. Firstly, the methodology of consulting files to extract the data left us at the mercy of the precision of the records of each autonomous community, where the differences found were enormous. Secondly, measuring the incidence of factors in terms of their presence or absence in the files always has the drawback of not knowing whether the fact that we do not find a certain variable indicates that it really was absent in this case or whether, for some reason, it was simply not included in the file. The rates of incidence of the diverse types of maltreatment reflected in our study are lower than those established in the national research (Del Valle \& Bravo, 2002; Palacios, 1995) and this is because the type of maltreatment received does not always appear explicitly in the files. The same can be said, for example, when the datum of an alcoholic father is missing, which is not the same thing as finding the explicit statement that the father is not an alcoholic. This uncertainty is characteristic of studies via files and we have tried to solve it by means of clarifying interviews with the case social worker, although there is always some degree of misgiving.

The assessment of programs should be addressed in our country, both in terms of results and of process in this sphere of foster care. Prevention of breakdown and the study of the risk factors of such breakdowns should be a priority, as well as the development of monitoring and recording systems for the careful analysis of each case; it is not possible to do this by means of retrospective studies of files. For example, the existence of such a relevant issue as behavior problems that cause breakdowns should lead to the detailed study of the diverse types of behaviors that fall under this label. Future lines of research should minutely examine each one of the risk factors found in this study.

\section{References}

Aldgate, J., \& Hawley, D. (1986). Preventing disruption in longterm foster care. Adoption and Fostering, 10, 23-30.

Barber, J. G., Delfabbro, P. H., \& Cooper, L. L. (2001). The predictors of unsuccessful transition to foster care. Journal of Child Psychology and Psychiatry, 42, 785-790. doi:10.1111/1469-7610.00775

Barth, R., \& Berry, M. (1988). Adoption and disruption: Rates, risks and responses. New York, NY: Aldine de Gruyter.

Berridge, D. (1997). Foster care: A research review. London, UK: The Stationery Office.

Berridge, D., \& Cleaver, H. (1987). Foster home breakdown. Oxford: Basil Blackwell.

Berry, M., \& Barth, R. P. (1990). A study of disrupted adoptive placements of adolescents. Child Welfare, 69, 209-225.

Biehal, N., Clayden, J., Stein, M., \& Wade, J. (1995). Moving on: Young people and leaving care schemes. London, UK: HMSO.

Bravo, A., \& Del Valle, J.F. (2009). Crisis and review of residential child care. Its role in child protection. Papeles del Psicólogo, 30, 42-52.

Brown, J., \& Calder, P. (1999). Concept mapping the challenges faced by foster parents. Children and Youth Services Review, 21, 481-495. doi:10.1016/S0190-7409(99)00034-1

Cautley, P. W. (1980). New foster parents: The first experience. New York, NY: Human Services Press.

Chamberlain, P. (1990). Comparative evaluation of specialized foster care for seriously delinquent youths: A first step. Community Alternatives: International Journal of Family Care, 2, 21-36.

Chamberlain, P., Leve, L. D., \& DeGarmo, D. S. (2007). Multidimensional treatment foster care for girls in the juvenile justice system: 2-year follow-up of a randomized clinical trial. Journal of Consulting and Clinical Psychology, 75, 187-193. doi:10.1037/0022-006X.75.1.187

Chamberlain, P., Price, J. M., Reid, J. B., Landsverk, J., Fisher, P. A., \& Stoolmiller, M. (2006). Who disrupts from placement in foster and kinship care? Child Abuse and Neglect, 30, 409-424. doi:10.1016/j.chiabu.2005.11.004

Chipungu, S. S., \& Everett, J. E. (1994). The power of information: Exchange patterns between African-American foster parents and child welfare workers. Journal of Multicultural Social Work, 3, 17-33. doi:10.1300/J285v03n03_02

Cooper, C. S., Peterson, N. L., \& Meier, J. H. (1987). Variables associated with disrupted placement in a select sample of abused and neglected children. Child Abuse and Neglect, 11, 75-86. doi:10.1016/0145-2134(87)90035-4 
Courtney, M., \& Barth, R. (1996). Pathways of older adolescents out of foster care: Implications for independent living services. Social Work, 41, 75-83.

Del Valle, J. F., Álvarez-Baz, E., \& Bravo, A. (2002). Acogimiento en familia extensa. Perfil descriptivo y evaluación de necesidades en una muestra del Principado de Asturias [Kinship foster care. Descriptive profile and needs assessment in a sample from the Principality of Asturias]. Bienestar $y$ Protección Infantil, 1, 34-56.

Del Valle, J. F., \& Bravo, A. (2002). Maltrato infantil: situación actual y respuestas sociales [Child abuse: current status and social responses]. Psicothema, 14, 118-123.

Del Valle, J. F., \& Bravo, A. (2003). La situación del acogimiento familiar en España [Situation of foster care in Spain]. Madrid: Ministerio de Trabajo y Asuntos Sociales. Retrieved from: http://www.gifi.es/admin/publicaciones/archives/77025 Acogimiento_2003.pdf

Del Valle, J. F., Bravo, A., \& López, M., (2009). El acogimiento familiar en España: implantación y retos actuales [Foster care in Spain. Its stablishment and current challenges]. Papeles del Psicólogo, 30, 33-41.

Del Valle, J. F., López, M., Montserrat, C., \& Bravo, A. (2008). El acogimiento familiar en España. Una evaluación de resultados [Foster care in Spain. An outcome assessment]. Madrid: Ministerio de Trabajo y Asuntos Sociales. Retrieved from: http://www.gifi.es/admin/publicaciones/archives/3920_ El_acogimiento.pdf.

Del Valle, J. F., López, M., Montserrat, C., \& Bravo, A. (2009). Twenty years of foster care in Spain: Profiles, patterns and outcomes. Children and Youth Services Review, 31, 847-853. doi:10.1016/j.childyouth.2009.03.007

Drapeau, S., Simard, M., Beaudry, M., \& Chardonneau, C. (2000). Siblings in family transitions. Family Relations, 49, 77-85. doi:10.1111/j.1741-3729.2000.00077.x

Eckenrode, J., Rowe, E., Laird, M., \& Brathwaite, J. (1995). Mobility as a mediator of the effects of child maltreatment on academic performance. Child Development, 66, 1130-1142. doi:10.1111/j.1467-8624.1995.tb00927.x

Fanshel, D., Finch, S. J., \& Grundy, J. F. (1990). Foster children in a life course perspective. New York, NY: Columbia University Press.

Farmer, E. R. G. (2009). Placement stability in kinship care. Vulnerable Children and Youth Studies, 4, 154-160. doi:10.1080/17450120902887871

Farmer, E., Lipscome, J., \& Moyers, S. (2005). Foster carer strain and its impact on parenting and placement outcomes for adolescents. British Journal of Social Work, 35, 237-253. doi:10.1093/bjsw/bch181

Farmer, E. R. G., \& Moyers, S. (2008). Kinship care: Fostering effective family and friends placements. London, UK: Jessica Kingsley.

Festinger, T. (1983). No one ever asked us: A postscript to foster care. New York, NY: Columbia University Press.

Fisher, T., Gibbs, I., Sinclair, I., \& Wilson, K. (2000). Sharing the care: The qualities sought of social workers by foster carers. Child and Family Social Work, 5, 225-233. doi:10.1046/ j.1365-2206.2000.00165.x
Fratter, J., Rowe, J., Sapsford, D., \& Thoburn, J. (1991). Permanent family placement: A decade of experience. London, UK: BAAF.

George, V. (1970). Foster care: Theory and practice. London, UK: Routledge \& Kegan.

Gilbertson, R., \& Barber, J. G. (2003). Breakdown of foster care placement: Carer perspectives and system factors. Australian Social Work, 56, 329-339. doi:10.1111/j.14470748.2003.00095.x

Gleeson, J., \& Hairston, F. C. (1999). Kinship care: Improving practice through research. Washington, DC: CWLA Press.

Gries, L. T., Goh, D. S., Andrews, M. B., Gilbert, J., Praver, F., \& Stelzer, D. N. (2000). Positive reaction to disclosure and recovery from child sexual abuse. Journal of Child Sexual Abuse, 9, 29-51. doi:10.1300/J070v09n01_03

Harwin, J, Owen, M, Locke, R., \& Forrester, D. (2001). Making care orders work: A study of care plans and their implementation. London, UK: The Stationery Office.

Heller, S. S., Smyke, A. T., \& Boris, N. W. (2002). Very young foster children and foster families: Clinical challenges and interventions. Infant Mental Health Journal, 23, 555-575. doi:10.1002/imhj.10033

Hudson, J., Nutter, R. W., \& Galaway, B. (1994). Treatment foster family care: Development and current status. Community Alternatives: International Journal of Family Care, 6, 1-24.

James, S., Landsverk, J., \& Slymen, D. J. (2004). Placement movement in out-of-home care: Patterns and predictors. Children and Youth Services Review, 26, 185-206. doi:10.1016/j.childyouth.2004.01.008

Jiménez, J. M., \& Palacios, J. (2008). El acogimiento familiar en Andalucía: Procesos familiares, perfiles personales [Foster care in Andalusia: Family processes, personal profiles]. Granada, Spain: Junta de Andalucía.

Kalland, M., \& Sinkkonen, J. (2001). Finnish children in foster care: Evaluating the breakdown of long-term placements. Child Welfare, 80, 513-527.

Laan, N. M. A., Loots, G. M. P., Janssen, C. G. C., \& Stolk, J. (2001). Foster care for children with mental retardation and challenging behavior: A follow-up study. British Journal of Developmental Disabilities, 47, 3-13

Leathers, S. J. (2006). Placement disruption and negative placement outcomes among adolescents in long-term foster care: The role of behavior problems. Child Abuse \& Neglect, 30, 307-324. doi:10.1016/j.chiabu.2005.09.003

Leslie, L., Gordon, J., Meneken, L., Premji, K., Michelmore, K., \& Ganger, W. (2005). The physical, developmental, and mental health needs of young children in child welfare by initial placement type. Journal of Developmental and Behavioral Pediatrics, 26, 177-185. doi:10.1097/00004703-20050600000003

McDonald, T., Lieberman, A., Partridge, S., \& Hornby, H. (1991). Assessing the role of agency services in reducing adoption disruptions. Children and Youth Services Review, 13, 425-438. doi:10.1016/0190-7409(91)90030-L 
Mech, E., Ludy-Dobson, C., \& Hulseman, F. S. (1994). Life-skills knowledge: A survey of foster adolescents in three placement settings. Children and Youth Services Review, 16, 181-200. doi:10.1016/0190-7409(94)90005-1

Milan, S. E., \& Pinderhughes, E. E. (2000). Factors influencing maltreated children's early adjustment in foster care. Development and Psychopathology, 12, 63-81. doi:10.1017/ S0954579400001048

Millham, S., Bullock, R., Hosie, K., \& Haak, M. (1986). Lost in care: The problems of maintaining links between children in care and their families. Aldershot, UK: Gower.

Minty, B. (1999). Outcomes in long-term foster family care. Journal of Child Psychology and Psychiatry, 40, 991-999. doi:10.1111/1469-7610.00518

Montserrat, C. (2007). Kinship foster care: A study from the perspective of the caregivers, the children and the child welfare workers. Psychology in Spain, 11, 42-52.

Montserrat, C., \& Casas, F. (2006). Kinship foster care from the perspective of quality of life: Research on the satisfaction of the stakeholders. Applied Research in Quality of Life, 1, 227237. doi:10.1007/s11482-007-9018-2

Napier, H. (1972). Success and failure in foster care. British Journal of Social Work, 2, 187-204.

Newton, R. R., Litrownik, A. J., \& Landsverk, J. A. (2000). Children and youth in foster care: Disentangling the relationship between problem behaviors and number of placements. Child Abuse and Neglect, 24, 1363-1374. doi:10.1016/S0145-2134(00)00189-7

Oosterman, M., Schuengel, C., Slot, N. W., Bullens, R. A. R., \& Doreleijers, T. A. H. (2007). Disruptions in foster care: A review and meta-analysis. Children and Youth Services Review, 29, 53-76. doi:10.1016/j.childyouth.2006.07.003

Palacios, J. (1995). Los datos del maltrato infantil en España: una visión en conjunto [Data on child abuse in Spain: An overview]. Infancia y Aprendizaje, 18, 69-75. doi:10.1174/02103709560575497

Palmer, S. E. (1996). Placement stability and inclusive practice in foster care: An empirical analysis. Children and Youth Services Review, 18, 589-601. doi:10.1016/0190-7409(96)00025-4

Pardeck, J. (1984). An exploration of factors associated with the stability and continuity of the foster care system in the United States. International Social Work, 27, 5-9. doi: $10.1177 / 002087288402700103$

Parker, R. (1966). Decision in child care: A study of prediction in fostering. London, UK: Allen \& Unwin.

Patten, P. (2005). Foster carers. Why they stay and why they leave. Child Care in Practice, 11, 92-94.

Proch, K., \& Taber, M. A. (1985). Placement disruption: A review of research. Children and Youth Services Review, 7, 309-320. doi:10.1016/S0190-7409(85)80004-9

Rich, H. (1996). The effects of a health newsletter for foster parents on their perceptions of the behaviour and development of foster children. Child Abuse and Neglect, 20, 437-445. doi:10.1016/0145-2134(96)00018-X

Rowe, J., Cain, H., Hundleby, M., \& Garnett, L. (1989). Child care now. London, UK: BAAF.
Sallnäs, M., Vinnerljung, B., \& Westermark, P. K. (2004). Breakdown of teenage placements in Swedish foster and residential care. Child and Family Social Work, 9, 141-152. doi:10.1111/j.1365-2206.2004.00309.x

Schwartz, I. M., Ortega, R., Guo, S., \& Fishman, G. (1994). Infants in non permanent placement. Social Service Review, 68, 405-416. doi:10.1086/604066

Sinclair, I., \& Wilson, K. (2003). Matches and mismatches: The contribution of carers and children to the success of foster placements. British Journal of Social Work, 33, 871-884. doi:10.1093/bjsw/33.7.871

Smith, M. C. (1994). Child rearing practices associated with better developmental outcomes in preschool-age foster children. Child Study Journal, 24, 299-326.

Stern, S. B., \& Smith, C. A. (1999). Reciprocal relationships between antisocial behavior and parenting: Implications for delinquency intervention. Families in Society: The Journal of Contemporary Human Services, 80, 169-181.

Stone, N. M., \& Stone, S. F. (1983). The prediction of successful foster placement. Social Casework: The Journal of Contemporary Social Work, 64, 11-17.

Terling-Watt, T. (2001). Permanency in kinship care: An exploration of disruption rates and factors associated with placement disruption. Children and Youth Services Review, 23, 111-126. doi:10.1016/S0190-7409(01)00129-3

Thompson, R. W., Authier, K., \& Ruma, P. (1994). Behavior problems of sexually abused children in foster care: A preliminary study. Journal of Child Sexual Abuse, 3, 79-91.

Thorpe, M. B., \& Swart, M. D. (1992). Risk and protective factors affecting children in foster care: A pilot study of the role of siblings. Canadian Journal of Psychiatry, 37, 616-622.

Trasler, G. (1960). In place of parents. London, UK: Routledge \& Kegan Paul.

Vanderfaeillie, J., Van Holen, F., \& Coussens, S. (2008). Why do foster care placements break down? An study into the factors influencing foster care placement breakdown in Flanders. International Journal of Child and Family Welfare, 11, 77-88.

Wade, J., Biehal, N., Clayden, J., \& Stein, M. (1998). Going missing: Young people absent from care. Chichester, UK: John Wiley \& Sons.

Walsh, J. A., \& Walsh, R. A. (1990). Studies of the maintenance of subsidized foster placements in the Casey Family Program. Child Welfare, 69, 99-114.

Webster, D., Barth, R. P., \& Needell, B. (2000). Placement stability for children in out-of-home care: A longitudinal analysis. Child Welfare, 79, 614-632.

Widom, C. S. (1991). The role of placement experiences in mediating the criminal consequences of early childhood victimization. American Journal of Orthopsychiatry, 61, 195209. doi:10.1037/h0079252

Received October 13, 2009

Revision received February 10, 2010

Accepted February 19, 2010 